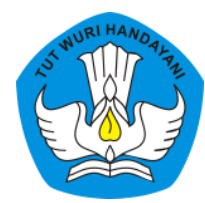

Page: 679-700

\title{
ANTUSIASME BELAJAR SISWA TERHADAP PEMBELAJARAN DIGITAL BERBASIS BCS-APP PADA MASA PANDEMI COVID-19
}

\author{
Dian Khoirul Huda \\ Sekolah Menengah Pertama Negeri 2 Praya Barat Daya, Lombok Tengah \\ Contributor Email: diankhoirulhuda.ggd@gmail.com
}

\begin{abstract}
The $21^{\text {st }}$ century requires human to be able to take advantage of technology, including in education. The COVID-19 pandemic is also pushing education to change from classic learning to distance learning utilizing digital technology. This matter encourages teachers to carry out a learning innovation by creating learning media that is able to encourage students to be more enthusiasm about long distance learning. The digital learning media of innovation in this research can be increase student's enthusiasm for learning in class 8.1 of Sekolah Menengah Pertama Negeri 2 Praya Barat Daya. The method used in this research is Research and Development (RED) with testing using media validation instrument, enthusiasm observation instrument and test questions instrument given to students. Obtained in average value of the media validation results of 88.33 with very good criteria, thus it can be said that the digital learning media of innovation in this research is suitable for use in learning. The results of the observation showed that the student's enthusiasm for learning had increased, in first learning obtained an average score of 54.12 increased at the second learning to $84.70 \%$. Learning outcomes also increased, in first learning the average score of students was 67.06 with classical completeness of $52.94 \%$ increased in second learningthe average score of students became 83.76 with classical completeness of $88.24 \%$.
\end{abstract}

Keywords: Enthusiasm for Learning, Digital Learning Media, Based on Android. 


\begin{abstract}
Abstrak
Abad ke-21 menuntut manusia untuk mampu memanfaatkan teknologi, termasuk dalam bidang pendidikan. Adanya pandemi Covid-19 juga mendorong pendidikan untuk berubah dari pembelajaran klasikal menjadi pembelajaran jarak jauh memanfaatkanteknologi digital. Hal ini mendorong guru untuk melakukan inovasi pembelajaran dengan membuat media pembelajaran yang mampu mendorong siswa lebih antusias dalam melakukan pembelajaran jarak jauh. Media pembelajaran digital hasil inovasi dalam penelitian ini mampu meningkatkan antusiasme belajar siswa di kelas 8.1 Sekolah Menengah Pertama Negeri 2 Praya Barat Daya. Metode yang digunakan dalam penelitian ini adalah penelitian dan pengembangan $(R \mathcal{E} D)$ dengan pengujian menggunakan instrumen validasi media, instrument observasi antusiame belajar siswa, dan instrumen soal tes yang diberikan kepada siswa. Diperoleh nilai rata-rata hasil validasi media sebesar 88,33 dengan kriteria sangat baik, dengan demikian dapat dikatakan media pembelajaran digital hasil inovasi dalam penelitian ini layak untuk digunakan dalam pembelajaran. Hasil observasi menunjukkan bahwa antusiame belajar siswa mengalami peningkatan, yaitu pada pembelajaran I diperoleh skor rata-rata sebesar 54,12\% meningkat pada pembelajaran II menjadi $84,70 \%$. Hasil belajar juga mengalami peningkatan, yaitu pada pembelajaran I nilai rata-rata siswa sebesar 67,06 dengan ketuntasan klasikal 52,94\% meningkat pada pembelajaran II nilai rata-rata siswa menjadi 83,76 dengan ketuntasan klasikal 88,24\%.
\end{abstract}

Kata Kunci: Antusiame Belajar, Media Pembelajaran Digital, Berbasis Android.

\title{
A. Pendahuluan
}

Era globalisasi pada abad ke-21 telah banyak mengubah kebiasaan manusia menuju ke arah penggunaan teknologi secara luas. Begitu juga bidang pendidikan, sehingga dalam pendidikan kita juga mengenal istilah pendidikan abad ke-21. Pendidikan abad ke-21 merupakan pendidikan yang mengintegrasikan penguasaan teknologi informasi dan komunikasi ke dalam kemampuan literasi, pengetahuan, keterampilan, serta sikap siswa (Wahyudin, 2018). Kegiatan pembelajaran yang menerapkan pembelajaran abad ke-21 juga dapat menjawab tantangan revolusi industri 4.0 terutama terkait dengan literasi digital dengan memanfaatkan media, teknologi, informasi, dan komunikasi (Kristiningrum, 2020). Berbagai upaya dalam rangka untuk menghadapi tantangan pendidikan abad ke-21, salah satunya guru diharapkan memiliki kemampuan untuk mengembangkan pembelajaran yang inovatif, aktif, dan kreatif. Pembelajaran yang inovatif, aktif, dan kreatif tersebut diharapkan dapat 
menghasilkan siswa yang memiliki kemampuan berfikir kreatif, kritis, komunikatif dan kolaboratif (Ariyana et al., 2019). Ada banyak cara untuk menjadi guru yang inovatif, aktif, dan kreatif dalam pembelajaran, salah satunya adalah memanfaatkan media dalam proses pembelajaran (Kuswanto \& Radiansah, 2018). Media pembelajaran merupakan alat untuk menyampaikan pesan-pesan pembelajaran (Arsyad, 2015). Saat ini, media pembelajaran yang sangat populer dan disenangi siswa adalah media pembelajaran yang menggunakan teknologi digital, salah satunya yang berbasis android (Yektyastuti \& Ikhsan, 2016).

Berdasarkan survei yang dilakukan oleh Aliansi Penyelenggara Jasa Internet Indonesia pada tahun 2016 menyatakan bahwa pengguna internet di Indonesia pada usia 10 - 24 tahun sebanyak 75,5\%, yaitu berada pada urutan kedua setelah pengguna internet pada usia 25-34 tahun yaitu sebanyak 75,8 \% (Farida, 2019). Hal ini menunjukkan bahwa anak usia sekolah sudah banyak yang memanfaatkan internet dalam kegiatan sehari-harinya. Begitu juga di Sekolah Menengah Pertama Negeri 2 Praya Barat Daya. Dari hasil pendataan yang dilakukan oleh operator sekolah dalam rangka kegiatan pembelajaran jarak jauh di kelas 8.1 yang berjumlah 17 siswa diketahui bahwa 14 di antaranya sudah memiliki gawai sendiri dan 3 siswa lainnya belum memiliki gawai sendiri, akan tetapi mereka bersedia untuk meminjam gawai milik orang tua atau keluarga mereka selama pembelajaran jarak jauh berlangsung. Berdasarkan hasil wawancara yang dilakukan oleh penulis, sebagian besar siswa mengaku memanfaatkan gawai yang dimiliki untuk berbagai kegiatan seperti media sosial, bermain game, mendengarkan musik, dan menonton video di YouTube. Mereka belum memanfaatkan gawai yang dimilikinya untuk menunjang kegiatan pembelajaran secara optimal.

Di akhir tahun 2019 hingga awal tahun 2021 ini di berbagai negara termasuk Indonesia sedang terjadi pendemi virus corona atau lebih dikenal dengan Covid-19 (Corona Virus Desease 2019). Penularan virus Covid-19 ini sangatlah cepat, penularan dapat melalui pegangan tangan 
dengan orang yang terinfeksi, dapat melalui percikan batuk orang yang terinfeksi bahkan dapat melalui udara. Pemerintah telah melakukan berbagai upaya dalam rangka mengantisipasi penyebaran virus Covid19,yaitu dengan mengeluarkan berbagai kebijakan antara lain isolasi, social and physical distancing, dan juga pembetasan sosial berskala besar (Sadikin \& Hamidah, 2020). Hal ini mendorong pemerintah pusat untuk mengadakan pembatasan pertemuan-pertemuan sehingga kantor-kantor dan sekolah-sekolah ditutup untuk sementara waktu, atau dikenal dengan kebijakan "bekerja dari rumah" untuk para pekerja kantor dan "belajar dari rumah" untuk anak sekolah dan mahasiswa (Astini, 2020).

Kondisi pandemi COVID-19 ini juga sangat berpengaruh terhadap pembelajaran di Sekolah Menengah Pertama Negeri 2 Praya Barat Daya. Pandemi Covid-19 yang mengharuskan jaga jarak sosial membuat pemerintah melalui Kementerian Pendidikan dan Kebudayaan mengatur pelaksanaan pembelajaran di masa pandemi Covid-19 yaitu melalui belajar dari rumah baik secara dalam jaringan (daring) maupun luar jaringan (luring)sesuai dengan Surat Edaran Mendikbud Nomor 4 Tahun 2020 tanggal 24 Maret 2020. Sehingga mulai akhir bulan Maret 2020 pembelajaran di Sekolah Menengah Pertama Negeri 2 Praya Barat Daya dilaksanakan secara jarak jauh melalui dalam jaringan (daring). Akan tetapi pembelajaran jarak jauh melalui daring tersebut kurang mendapat respons positif dari siswa terkait dengan semangat atau antusiasme belajarnya, karena mereka cenderung kesulitan untuk belajar dengan cara belajar daringyang dilaksanakan para guru. Pembelajaran daringyang dilaksanakan di Sekolah Menengah Pertama Negeri 2 Praya Barat Daya yaitu dengan menggunakan aplikasi Whatsapp dengan sistem belajar modul. Hampir semua guru memiliki cara belajar yang sama yaitu dengan sistem modul. Berdasarkan wawancara yang dilakukan penulis terhadap siswa kelas 8.1 Sekolah Menengah Pertama Negeri 2 Praya Barat Daya menunjukkan bahwa sejak terjadinya pandemi COVID-19 siswa kurang bersemangat dan kurang antusias dalam belajar, hal ini dikarenakan siswa cenderung malas membaca 
modul-modul yang dibagikan guru dalam setiap proses pembelajaran jarak jauh secara daring.

Berdasarkan kondisi yang telah diuraikan di atas, penulis berkeinginan untuk membangkitkan antusiasme belajar siswa dengan tujuan supaya siswa mampu mencapai keberhasilan dalam belajarnya. Antusiasme merupakan rasa semangat, ketertarikan, atau kegairahan terhadap suatu hal. Antusiasme belajar siswa bisa diartikan sebagai semangat, ketertarikan, atau kegairahan siswa itu sendiri untuk melaksanakan kegiatan belajar (Sriningsih, 2019). Upaya untuk membangkitkan antusiasme belajar siswa tersebut penulis mengembangkan media pembelajaran digital berbasis android. Media pembelajaran digital berbasis android sebagai sarana pembelajaran lebih efektif untuk membangkitkan antusiasme belajar siswa karena lebih menarik dibandingkan dengan sistem modul. Pemilihan media pembelajaran digital berbasis android ini juga didasarkan pada adanya kebijakan pembelajaran jarak jauh, kepemilikan gawai oleh siswa, serta sesuai dengan perkembangan jaman pada abad 21 ini. Media pembelajaran digital berbasis android yang dikembangkan oleh penulis adalah BCS-App. BCS-App merupakan aplikasi pembelajaran berbasis android yang dikembangkan sendiri oleh penulis menggunakan salah satu alat pembuat aplikasi android yaitu Smart Apps Creator (SAC).

Terdapat beberapa penelitian yang relevan dalam penelitian ini, yaitu penelitian yang dilakukan oleh Muyaroah \& Fajartia (2017) dalam Innovatif Jurnal of Curriculum and Educational Tecnology, dengan judul penelitian "Pengembangan Media Pembelajaran Berbasis Android dengan Menggunakan Aplikasi Adobe Flash CS 6 pada Mata Pelajaran Biologi". Tujuan penelitian ini yaitu untuk mengembangkan sebuah media pembelajaran mobile learning berbasis android serta untuk mengetahui efektivitasnya terhadap hasil belajar siswa. Penelitian lainnya dilakukan oleh Nugraheni (2017) dalam prosiding HIPKIN Jateng, dengan judul penelitian "Multimedia Pembelajaran Digital untuk Meningkatkan 
Antusiasme Siswa dalam Belajar". Tujuan penelitian ini adalah untuk menciptakan inovasi dalam menunjang proses pembelajaran dan untuk mengetahui peningkatan antusiasme siswa dalam proses pembelajaran dengan digunakannya multimedia pembelajaran digital.

\section{B. Metode}

Penelitian ini menggunakan metode penelitian dan pengembangan (RED). Menurut Sugiyono (2017), metode Penelitian dan Pengembangan $(R \mathcal{E} D)$ merupakan metode penelitian yang digunakan untuk menghasilkan produk tertentu berdasarkan analisis kebutuhan, serta menguji keefektifan media tersebut agar dapat digunakan secara luas. Teknik analisis data dalam penelitian ini yaitu untuk cara pembuatan media atau produk adalah dengan deskriptif kualitatif, sedangkan untuk hasil uji keefektifan media dianalisis menggunakan teknik deskriptif kuantitatif perbandingan persentase.

Subjek dalam penelitian ini adalah siswa kelas 8.1 Sekolah Menengah Pertama Negeri 2 Praya Barat Daya yang berjumlah 17 siswa. Materi yang digunakan adalah sistem peredaran darah pada manusia. Teknik pengumpulan data dalam penelitian ini menggunakan metode observasi dan tes yang dilakukan secara online. Data antusiasme belajar siswa diperoleh dengan menggunakan lembar observasi yang berisi empat indikator antusiasme siswa yaitu respons, perhatian, kesadaran, dan partisipasi. Sedangkan untuk data pendukung berupa data hasil belajar siswa,diperoleh dengan menggunakan soal-soal tes yang diberikan kepada siswa di akhir pembelajaran.

Menurut Borg dan Gall dalam Astutik (2019), prosedur penelitian yang dilakukan dalam mengembangkan dan memvalidasi produk Pendidikan adalah (1) penelitian dan pengumpulan data, (2) perencanaan, (3) pengembangan produk awal, (4) uji coba produk awal/ uji terbatas,(5) penyempurnaan produk awal, (6) uji coba lebih luas, (7) penyempurnaan produk hasil uji coba lebih luas, (8) uji coba produk akhir, (9) 
penyempurnaan produk akhir, (10) validasi media, (11) implementasi, (12) diseminasi. Secara lebih rinci langkah-langkah prosedur penelitian ini adalah sebagai berikut.

1. Penelitian dan pengumpulan data

Pada langkah ini data diperoleh dari data hasil penilaian harian materi sistem peredaran darah pada manusia. Data tersebut menunjukkan bahwa masih banyak siswa yang belum mencapai kriteria ketuntasan minimal yaitu 70 . Setelah guru melakukan wawancara ternyata masih banyak siswa yang kurang tertarik/antusias selama pembelajaran jarak jauh yang telah dilakukan. Mereka mengaku malas membaca modul yang diberikan oleh guru, sehingga sangat memengaruhi hasil belajar mereka.

\section{Perencanaan}

Pada langkah ini peneliti mengubah strategi dalam pembelajaran, terutama dalam penggunaan media. Hal ini dikarenakan siswa mengaku malas membaca modul yang diberikan oleh guru. Oleh karena itu, peneliti membuat media pembelajaran yang menarik agar siswa lebih antusias dalam belajar berupa media pembelajaran digital berbasis android yang diberi nama BCS-App. BCS-App merupakan singkatan dariBlood Circulation System -Applicationyang jika dalam bahasa Indonesia artinya Aplikasi Sistem Peredaran Darah.

\section{Pengembangan produk awal}

Peneliti membuat media pembelajaran berbentuk aplikasi berbasis androiddengan menggunakan alat Smart Apps Creator (SAC). Smart Apps Creator (SAC) merupakan sebuah alat pembuat aplikasi android yang dijalankan menggunakan laptop atau PC. Alat ini dipilih setelah peneliti melakukan konsultasi dengan beberapa teman guru tentang alat pembuat aplikasi yang mudah dalam penerapannya. 
4. Uji coba produk awal/uji terbatas

Setelah aplikasi BCS-Apptelah jadi, peneliti melakukan uji coba terbatas kepada beberapa guru yang ada di Sekolah Menengah Pertama Negeri 2 Praya Barat Daya. Teknis pelaksanaan kegiatan ini yaitu peneliti mendemonstrasikan media kemudian meminta beberapa guru untuk mencoba dan memberikan masukan terhadap media pembelajaran BCSApptersebut.

\section{Penyempurnaan produk awal}

Pada langkah ini peneliti memperbaiki media aplikasi yang telah dibuat berdasarkan masukan dari bapak/ibu guru yang terlibat dalam ujicoba terbatas. Perbaikan yang dilakukan terkait pemilihan gambar yang kurang sesuai, animasi, serta beberapa materi yang dirasa masih kurang.

\section{Uji coba lebih luas}

Pada langkah ini peneliti melakukan uji coba yang lebih luas, yaitu kepada guru-guru dari sekolah lain. Pada uji coba lebih luas ini juga masih ditemukan masukan terkait dengan tata letak serta adanya watermark pada aplikasi sehingga membuat aplikasi yang dibuat kurang bagus dilihat.

7. Penyempurnaan produk hasil uji coba lebih luas

Peneliti memperbaiki tata letak gambar dan tulisan, serta berusaha untuk mencari cara agar watermark pada aplikasi bisa dihilangkan. Setelah berkonsultasi dengan ahli media, peneliti mampu membuat aplikasi tanpa ada watermak pada aplikasi tersebut.

8. Uji coba produk akhir

Uji coba produk akhir diberikan kepada siswa kelas 9.1 Sekolah Menengah Pertama Negeri 2 Praya Barat Daya yang berjumlah 22 siswa. Selama ujicoba ini, siswa sangat antusias dan tertarik dalam menggunakan media aplikasi BCS-Appyang mereka gunakan. Hal ini dilihat dari ketertarikan serta respon mereka terhadap materi yang diajarkan. 


\section{Penyempurnaan produk akhir}

Penyempurnaan produk akhir hanya pada penataan tombol suara agar lebih menarik dan efisien dalam penggunaannya. Sebelumnya untuk menyalakan dan mematikan suara menggunakan dua tombol yang berbeda, namun pada tahap ini telah diperbaiki sehingga untuk mematikan dan menghidupkan suara menggunakan satu tombol saja.

10. Validasi Media

Validasi media diperlukan untuk mengetahui dan meningkatkan kualitas serta keabsahan media yang dibuat, validasi tersebut dilakukan oleh para ahli. Validasi media dalam penelitian ini dilakukan oleh 3 ahli, yaitu ahli media, ahli materi, dan praktisi.

\section{Implementasi}

Implementasi dilaksanakan di kelas 8.1 Sekolah Menengah Pertama Negeri 2 Praya Barat Daya yang berjumlah 17 siswa. Implementasi dilaksanakan selama 2 kali pertemuan, dalam setiap pertemuan guru melakukan observasi dan setiap selesai pembelajaran baik pertemuan pertama maupun pertemuan kedua siswa diberikan soal tes evaluasi.

\section{Diseminasi}

Diseminasi dilaksanakan kepada guru-guru mata pelajaran Ilmu Pengetahuan Alam kecamatan Praya Barat Daya melalui Musyawarah Guru Mata Pelajaran setempat, serta beberapa guru Ilmu Pengetahuan Alam dari kecamatan lain. Diseminasi ini dilakukan dengan cara guru mempresentasikan serta mendemonstrasikan penggunaan media yang telah dibuat, dan meminta peserta diseminasi untuk mencoba aplikasi tersebut.

\section{Hasil dan Pembahasan}

Berdasarkan penelitian yang telah dilakukan oleh penulis mulai dari pembuatan media hingga diterapkan pada siswa kelas 8.1 Sekolah Menengah Pertama Negeri 2 Praya Barat Daya diperoleh hasil dan pembahasan sebagai berikut. 


\section{Hasil}

Data hasil penelitian diurutkan sesuai dengan rumusan masalah pada penelitian ini yaitu sebagai berikut.

a. Langkah-langkah Pengembangan Media Pembelajaran BCS-App

Media pembelajaran BCS-App merupakan sebuah media pembelajaran digital berbasis android yang dikembangkan menggunakan alat pembuat aplikasi android yaitu Smart Apps Creator (SAC)dengan materi sistem peredaran darah pada manusia. Smart Apps Creator (SAC) merupakan alat pembuat aplikasi android yang mudah karena tanpa memerlukan kemampuan codding dalam proses pembuatannya. Alur pengembangan media pembelajaran $B C S-A p p$ secara umum adalah sebagai berikut. (1) Melakukan analisis kebutuhan siswa, (2) melakukan analisis media yang sesuai untuk kebutuhan siswa, (3) menyiapkan alat dan bahan dalam pembuatan media (laptop, aplikasi pembuat media, aplikasi pendukung, jaringan internet), (4) membuat/mengembangkan media.

Langkah-langkah pengembangan media pembelajaran BCS-App adalah sebagai berikut. (1) Meng-install alat/aplikasi pembuat media, pada penelitian pengembangan ini penulis menggunakan aplikasi Smart Apps Creator (SAC), (2) membuka aplikasi Smart Apps Creator (SAC), (3) memilih opsi tipe gawai yaitu tipe android phone dengan layout landscape, (4) menyisipkan latar atau background media, (5) menyisipkan gambar dan tombol, (6) membuat dan memodifikasi teks, (7) membuat menu utama, (8) membuat tujuan pembelajaran, (9) membuat materi pembelajaran, (10) membuat kuis atau latihan soal, (11) membuat profil pengembang, (12) mengatur interaksi tombol, transisi, musik, animasi, efek, dan asesoris lainnya yang menunjang tampilan, (13) melakukan preview tampilan, (14) mengecek ulang jika ditemukan kesalahan setelah preview hasil,(15) melakukan ekspor media menjadi format apk, (16) mengirim file apk ke gawai android, (17) meng-install dan mengoperasikan media melalui gawai android. 
b. Langkah-langkah dalam Penerapan Pembelajaran Digital berbasis BCS-App pada Masa Pandemi Covid-19

Langkah-langkah dalam penerapan media pembelajaran BCS-App pada masa pandemi Covid-19 adalah sebagai berikut. (1) Guru membuka pembelajaran jarak jauh melalui whatsapp group; (2) Guru memimpin doa dan mengecek kehadiran siswa; (3) Guru mengecek apakah semua siswa sudah meng-install aplikasi BCS-App atau masih ada yang belum; (4) Guru menjelaskan tata cara menggunakan media pembelajaran BCS-App; (5) Guru meminta siswa mempelajari materi dan menjawab latihan/kuis yang ada pada media pembelajaran BCS-App; (6) Guru memberi kesempatan kepada siswa untuk bertanya terkait dengan materi yang telah dipelajari; (7) Guru membuka ruang diskusi dengan siswa terkait dengan materi yang telah dipelajari; (8) Guru meminta siswa mengerjakan soal tes yang dikirim kepada siswa melalui Google Form; (9) Guru mengisi lembar observasi antusiasme belajar siswa selama proses pembelajaran jarak jauh berlangsung; (10) Guru menutup pembelajaran.

\section{c. Data Hasil Validasi Media BCS-App}

Validasi media diperlukan untuk mengetahui dan meningkatkan kualitas serta keabsahan media yang dibuat. Validasi tersebut dilakukan oleh para ahli. Validasi media dalam penelitian ini dilakukan oleh 3 ahli, yaitu ahli media, ahli materi, dan praktisi.

Berikut adalah data hasil validasi media yang diperoleh dari hasil penilaian oleh para ahli.

Tabel 1. Data Hasil Validasi Media

\begin{tabular}{clcl}
\hline No. & \multicolumn{1}{c}{ Validator } & Hasil Validasi & Kriteria \\
\hline 1. & Ahli Media & 85 & Sangat Baik \\
2. & Ahli Materi & 90 & Sangat Baik \\
3. & Praktisi & 90 & Sangat Baik \\
\hline & Rata-rata & 88,33 & Sangat Baik \\
\hline
\end{tabular}

Dari data di atas didapat nilai rata-rata validasi sebesar 88,33 dengan kriteria sangat baik (Sugiyono, 2017). Dengan demikian, dapat 
dikatakan bahwa media BCS-Applayak untuk digunakan sebagai media pembelajaran.

d. Data Hasil Observasi Antusiame Belajar Siswa

Penelitian ini dilaksanakan di dalam satu kelas sebanyak 2 pertemuan yang dilaksanakan secara daring. Pertemuan pertama atau selanjutnya disebut dengan pembelajaran I merupakan pembelajaran dengan menggunakan media berupa modul digital yang dikirimkan kepada siswa melalui WhatsApp group. Pertemuan kedua atau selanjutnya disebut dengan pembelajaran II merupakan pembelajaran dengan menggunakan media BCS-App, media BCS-App merupakan media pembelajaran berbasis android yang dikembangkan sendiri oleh penulis dengan menggunakan aplikasi Smart Apss Creator (SAC). Selama proses pembelajaran baik pada pembelajaran I maupun pada pembelajaran II, guru melakukan observasi untuk mengisi instrumen observasi antusiasme belajar siswa. Di setiap akhir dari pembelajaran, baik pembelajaran I maupun pembelajaran II guru memberikan soal tes melalui google form yang harus dikerjakan oleh siswa.

Adapun data hasil observasi antusiasme belajar siswa pada pembelajaran I dapat dilihat pada uraian berikut.

Tabel 2. Data Hasil Observasi Antusiasme Belajar Siswa pada

Pembelajaran I

\begin{tabular}{clccl}
\hline No. & $\begin{array}{c}\text { Indikator antusiame } \\
\text { belajar siswa }\end{array}$ & Jumlah skor & $\begin{array}{c}\text { Persentase } \\
\mathbf{( \% )}\end{array}$ & Kriteria \\
\hline 1. & Respon & 12 & 70,59 & Baik \\
2. & Perhatian & 7 & 41,18 & Cukup \\
3. & Kesadaran & 9 & 52,94 & Cukup \\
4. & Partisipasi & 12 & 70,59 & Baik \\
5. & Percaya diri & 6 & 35,29 & Kurang \\
\hline & Rata-rata & 9,2 & 54,12 & Cukup \\
\hline
\end{tabular}

Sedangkan data hasil observasi antusiasme belajar siswa pada pembelajaran II dapat dilihat pada uraian berikut. 
Dian Khoirul Huda

Tabel 3. Data Hasil Observasi Antusiasme Belajar Siswa pada

Pembelajaran II

\begin{tabular}{clccl}
\hline No. & $\begin{array}{c}\text { Indikator antusiame } \\
\text { belajar siswa }\end{array}$ & Jumlah skor & $\begin{array}{c}\text { Persentase } \\
\mathbf{( \% )}\end{array}$ & Kriteria \\
\hline 1. & Respon & 17 & 100 & Sangat Baik \\
2. & Perhatian & 14 & 82,35 & Sangat Baik \\
3. & Kesadaran & 14 & 82,35 & Sangat Baik \\
4. & Partisipasi & 15 & 88,23 & Sangat Baik \\
5. & Percaya diri & 12 & 70,59 & Baik \\
\hline & Rata-rata & 14,4 & 84,70 & Sangat Baik \\
\hline
\end{tabular}

Berdasarkan tabel 2 dan 3 di atas menunjukkan skor rata-rata antusiasme belajar siswa mengalami peningkatan. Pada pembelajaran I skor rata-rata siswa sebesar $54,12 \%$ dengan kriteria cukup, sedangkan pada pembelajaran II skor rata-rata siswa meningkat menjadi $84,70 \%$ dengan kriteria sangat baik (Sugiyono, 2017). Peningkatan antusiame belajar siswa di atas dapat digambarkan dengar diagram berikut.

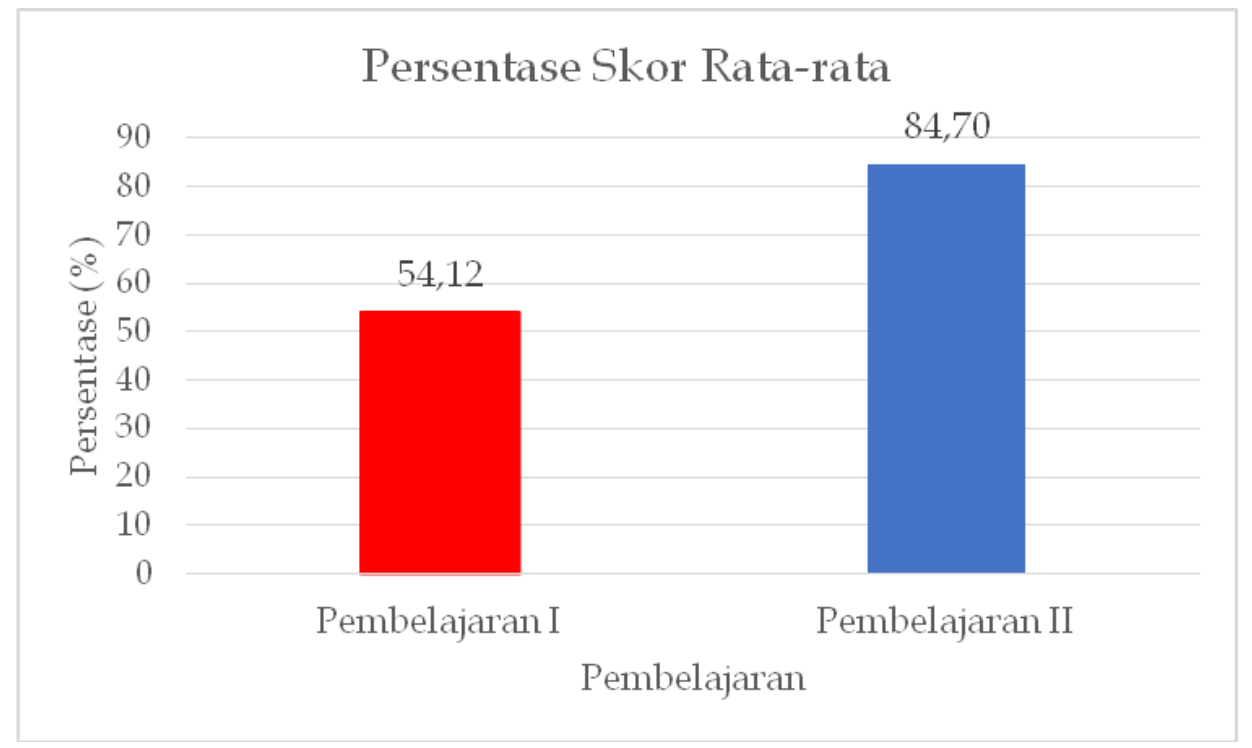

Gambar 1. Peningkatan Persentase Skor Rata-rata Antusiasme Belajar Siswa

e. Data Hasil Belajar Siswa

Adapun data hasil belajar pada pembelajaran Idan pembelajaran II dapat dilihat pada tabel berikut. 
Tabel 4. Hasil Belajar Siswa pada Pembelajaran I dan Pembelajaran II

\begin{tabular}{ccccc}
\hline $\begin{array}{c}\text { Pembelajaran } \\
\text { ke }\end{array}$ & $\begin{array}{c}\text { Jumlah } \\
\text { Siswa } \\
\text { Hadir }\end{array}$ & $\begin{array}{c}\text { Nilai Rata- } \\
\text { rata }\end{array}$ & $\begin{array}{c}\text { Jumlah Siswa } \\
\text { Tuntas }\end{array}$ & $\begin{array}{c}\text { Ketuntasan } \\
\text { Klasikal }\end{array}$ \\
\hline I & 17 & 67,06 & 9 & 52,94 \\
II & 17 & 83,76 & 15 & 88,24 \\
\hline
\end{tabular}

Tabel 4 di atas menunjukkan bahwa hasil belajar mengalami peningkatan. Pada pembelajaran I nilai rata-rata siswa sebesar 67,06 dengan ketuntasan klasikal 52,94\%, sedangkan pada pembelajaran II nilai rata-rata siswa meningkat menjadi 83,76 dengan ketuntasan klasikal $88,24 \%$. Peningkatan hasil belajar siswa di atas dapat digambarkan dengan diagram berikut.

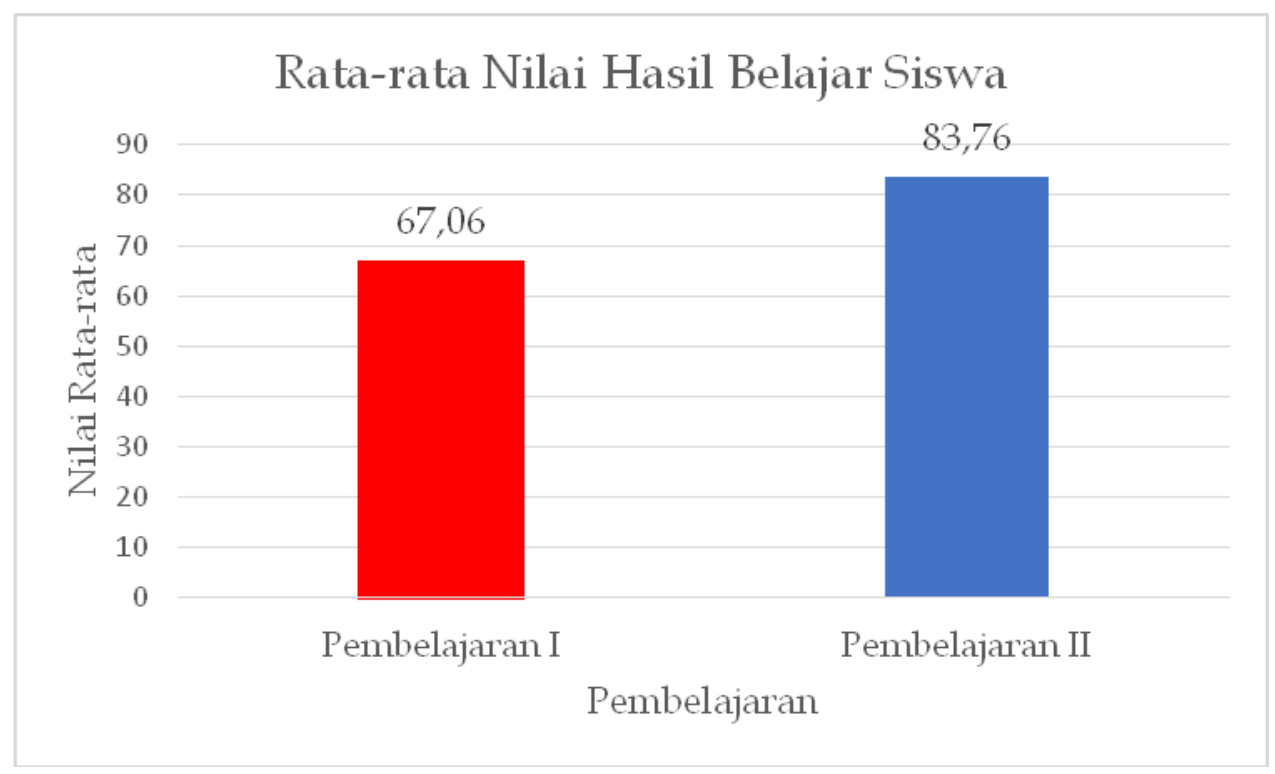

Gambar 2. Peningkatan Rata-rata Nilai Hasil Belajar Siswa

\section{Pembahasan}

Media pembelajaran BCS-Apps merupakan media pembelajaran digital berbasis android yang dikembangkan dengan menggunakan aplikasi Smart Apps Creator (SAC) dengan materi sistem peredaran darah pada manusia. Pemilihan Smart Apps Creator (SAC) sebagai alat pembuat 
aplikasi android dikarenakan Smart Apps Creator (SAC) sangat mudah dan tidak memerlukan kemampuan coding atau pemrograman dalam proses pengoperasiannya. Pemilihan materi sistem peredaran darah pada manusia ini dikarenakan berdasarkan analisis materi tersebut membutuhkan gambar dan animasi untuk memperjelas isi materi serta analisis kebutuhan siswa terkait materi tersebut. Setelah melalui beberapa tahapan pengembangan media hingga media pembelajaran BCS-App selesai diproduksi dan diterapkan kepada siswa, diketahui beberapa kelebihan dan kekurangan media. Kelebihan media pembelajaran BCSApp antara lain: (1) cara pembuatannya mudah tanpa menggunakan codding atau pemrograman, (2) mudah dioperasikan oleh siswa, (3) memiliki tampilan yang menarik dari segi warna, gambar, animasi, (4) terdapat gambar yang memperjelas materi, (5) terdapat soal latihan/kuis, (6) dapat dipelajari kapan saja dan di mana saja, (7) tanpa menggunakan kuota/tidak terhubung dengan jaringan internet (gratis). Sedangkan kekurangan media pembelajaran BCS-App antara lain sebagai berikut. (1) Belum bisa diunggah di playstore sehingga harus dikirim secara manual ke gawai pengguna atau dapat juga di unduh melalui drive pemilik (pengembang); (2) Ukuran aplikasi kurang lebih 50 megabite sehingga cukup besar untuk di-install di gawai siswa yang memorinya kecil, untuk itu membutuhkan gawai dengan spesifikasi minimal RAM 2 dan memori internal 16 GB agar aplikasi dapat berjalan dengan lancar (Kuswanto \& Radiansah, 2018); (3) Produk hanya membahas materi tentang sistem peredaran darah pada manusia; (4) Jumlah soal latihan/kuis terbatas.

Langkah-langkah pengembangan media pembelajaran BCS-App dalam penelitian ini menemui beberapa kendala, antara lain sebagai berikut. (1) Alat pembuat yaitu aplikasi Smart Apps Creator (SAC) yang digunakan oleh peneliti adalah versi trial sehingga hasil produk tidak bisa di unggah di playstore; (2) Versi trial hanya bisa digunakan selama 30 hari sejak peng-install-an sehingga ketika lebih dari 30 hari setelah peng-installan peneliti/pengembang harus memundurkan tanggal pada laptop/PC 
pada saat hendak membuka aplikasi Smart Apps Creator (SAC)tersebut; (3) Kurangnya referensi yang didapatkan oleh peneliti terkait aplikasi Smart Apps Creator (SAC).Berdasarkan kekurangan yang peneliti sampaikan di atas, peneliti berharap para peneliti berikutnya yang hendak memanfaatkan aplikasi Smart Apps Creator (SAC) untuk membeli lisensi aplikasi (tidak menggunakan versi trial) sehingga bisa berkreasi lebih maksimal dalam menggunakan Smart Apps Creator (SAC) tersebut.

Penerapan media pembelajaran BCS-Apppada masa pandemi Covid-19 dilakukan pada saat sistem pembelajaran di sekolah menerapkan sistem pembelajaran jarak jauh (daring), sehingga peran media digital sangat penting agar pembelajaran jarak jauh dapat berjalan dengan maksimal (Astini, 2020). Namun demikian, karena sistem pembelajaran jarak jauh (daring) merupakan sistem pembelajaran yang baru bagi siswa maupun guru, maka terdapat beberapa kendala dalam proses pelaksanaannya.

Langkah-langkah dalam penerapan media pembelajaran BCSApppada masa pandemi COVID-19 di Sekolah Menengah Pertama Negeri 2 Praya Barat Daya menemui beberapa kendala, antara lain: (1) guru tidak bisa memantau/mengetahui secara langsung apakah semua siswa mengikuti kegiatan pembelajaran secara penuh ataukah hanya mengikuti sebagian kegiatan pembelajaran saja, (2) jaringan sinyal siswa yang kurang stabil sehingga adanya keterlambatan pesan masuk, (2) beberapa siswa status gawai yang digunakan adalah meminjam sehingga siswa tersebut kurang terampil dan kurang leluasa dalam menggunakannya. Hambatan lain yang terjadi dalam pembelajaran jarak jauh (daring) menurut Anugrahana (2020) adalah tidak adanya pendampingan oleh orang tua/wali dalam proses pembelajaran daring sehingga kegiatan pembelajaran kurang terkontrol secara maksimal.

Setelah media pembelajaran BCS-App telah selesai dibuat dan siap untuk diterapkan dalam kegiatan pembelajaran, sebelumnya peneliti melakukan validasi media untuk mengetahui kualitas dan keabsahan 
media yang telah dibuat atau dikembangkan tersebut. Validasi dilakukan oleh 3 ahli, yaitu ahli media, ahli materi, dan praktisi. Ahli media yang berperan dalam penelitian ini adalah guru senior mata pelajaran TIK, ahli materi yang berperan dalam penelitian ini adalah guru senior mata pelajaran IPA, dan praktisi yang berperan dalam penelitian ini adalah rekan guru mata pelajaran Ilmu Pengetahuan Alam dari sekolah lain. Nilai rata-rata hasil validasi ketiga ahli sebesar 88,33 dengan kriteria sangat baik (Sugiyono, 2017). Dengan demikian, dapat dikatakan bahwa media BCS-App layak untuk digunakan sebagai media dalam pembelajaran. Berdasarkan penilaian oleh para ahli dapat disimpulkan bahwa dari aspek media, BCS-Appini memiliki tampilan yang menarik, baik dari segi gambar, warna, dan animasinya. Sedangkan dari aspek materi, materi sudah sesuai dengan tujuan atau kompetensi yang ingin dicapai, materi disajikan dengan cara yang runut dan lengkap, serta disertai gambar-gambar yang sesuai dan dapat memperjelas isi materi.

Hasil penelitian ini mendukung hasil penelitian yang telah dilakukan oleh Arliza et al., (2019) yang menyatakan bahwa hasil kelayakan persentase media pembelajaran interaktif berbasis android sebesar $80 \%$ dan dinyatakan layak untuk digunakan sebagai media dalam pembelajaran. Selain itu, hasil penelitian ini juga mendukung hasil penelitian yang dilakukan oleh Chahyanto \& Wantoro (2019) yang menyatakan bahwa hasil kelayakan media dengan persentase kelayakan sebesar 78,94\%dan termasuk kategori layak sehingga media pembelajaran berbasis android layak digunakan siswa dalam belajar.

Antusiasme belajar siswa pada penelitian ini meningkat setelah diterapkan pembelajaran dengan menggunakan media pembelajaran digital berbasis BCS-App. Peningkatan tersebut dapat dilihat dari peningkatan skor rata-rata antusiasme belajar siswa, yaitu pada pembelajaran I skor rata-rata antusiasme belajar siswa sebesar 54,12\% dengan kriteria cukup, sedangkan pada pembelajaran II skor rata-rata antusiasme belajar siswa meningkat menjadi 84,70\% dengan kriteria sangat baik. Berdasarkan indikator respons, jumlah siswa yang merespons pembelajaran pada pembelajaran I meningkat dari 12 siswa menjadi 17 
siswa pada pembelajaran II. Berdasarkan indikator perhatian, jumlah siswa yang memperhatikan pembelajaran pada pembelajaran I meningkat dari 7 siswa menjadi 14 siswa pada pembelajaran II. Berdasarkan indikator kesadaran, jumlah siswa yang sadar akan tugasnya pada pembelajaran I meningkat dari 9 siswa menjadi 14 siswa pada pembelajaran II. Berdasarkan indikator partisipasi, jumlah siswa yang berpartisipasi aktif dalam diskusi pembelajaran pada pembelajaran I meningkat dari 12 siswa menjadi 15 siswa pada pembelajaran II. Berdasarkan indikator percaya diri, jumlah siswa yang percaya diri menyampaikan hasil kerjanya pada pembelajaran I meningkat dari 6 siswa menjadi 12 siswa pada pembelajaran II.

Hasil penelitian ini mendukung hasil penelitian yang dilakukan oleh Nugraheni (2017) yang menyatakan bahwa menggunakan multimedia digital dapat meningkatkan antusiasme siswa dalam belajar.

Hasil belajar siswa pada penelitian ini menunjukkan bahwa mengalami peningkatan. Peningkatan tersebut dapat dilihat pada pembelajaran I diperoleh nilai rata-rata hasil belajar siswa sebesar 67,06 dengan ketuntasan klasikal 52,94\% dan meningkat pada pembelajaran II yaitu diperoleh nilai rata-rata hasil belajar siswa menjadi 83,76 dengan ketuntasan klasikal 88,24\%.

Hasil penelitian ini mendukung hasil penelitian yang dilakukan oleh Muyaroah \& Fajartia (2017) yang menyatakan bahwa penggunaan media pembelajaran berbasis android dapat meningkatkan hasil belajar siswa. Selain itu, hasil penelitian ini juga mendukung hasil penelitian yang dilakukan oleh Chahyanto \& Wantoro (2019) yang menyatakan bahwa menggunakan media pembelajaran berbasis android dapat meningkatkan hasil belajar siswa.

\section{Penutup}

Berdasarkan hasil penelitian dapat diketahui bahwa media pembelajaran BCS-App berbasis android yang telah dikembangkan dan diterapkan di Sekolah Menengah Pertama Negeri 2 Praya Barat Daya 
dapat meningkatkan antusiasme belajar siswa pada masa pandemi Covid19. Hal ini juga didukung dengan adanya peningkatan hasil belajar siswa dan juga peningkatan ketuntasan klasikal. Selain itu media pembelajaran BCS-App menurut para ahli sebagai validator menyatakan bahwa media ini layak untuk digunakan sebagai media dalam pembelajaran.

\section{Ucapan Terima Kasih}

Terima kasih penulis sampaikan kepada para guru yang terlibat dalam pelaksanaan penelitian ini, mulai dari pengembangan media hingga pelaksanaan penerapan media dalam pembelajaran. Terutama penulis sampaikan terima kasih kepada kepala Sekolah Menengah Pertama Negeri 2 Praya Barat Daya yang telah memberi dukungan dalam penelitian ini. Serta kepada para validator media yang telah berkenan memberikan validasi pada media yang penulis kembangkan. Semoga hasil penelitian ini dapat bermanfaat serta dapat membantu dalam memajukan pendidikan di Indonesia.

\section{Daftar Referensi}

Anugrahana, A. (2020). Hambatan, Solusi dan Harapan: Pembelajaran Daring Selama Masa Pandemi Covid-19 Oleh Guru Sekolah Dasar. Scholaria: Jurnal Pendidikan Dan Kebudayaan, 10(3), 282-289. https://doi.org/10.24246/j.js.2020.v10.i3.p282-289

Ariyana, Y., Ari Pujiastuti., Reisky Bestary., \& Zamroni. (2019). Buku Pegangan Pembelajaran Berorientasi pada Keterampilan Berfikir Tingkat Tinggi. Ditjen GTK Kemdikbud.

Arliza, R., Setiawan, I., \& Yani, A. (2019). Pengembangan Media Pembelajaran Interaktif Berbasis Android Materi Budaya Nasional Dan Interaksi Global Pendidikan Geografi. Jurnal Petik, 5(1), 77-84. https://doi.org/10.31980/jpetik.v5i1.493

Arsyad, A. (2015). Media Pembelajaran. Jakarta: Raja Grafindo Persada.

Astini, N. K. S. (2020). Pemanfaatan Teknologi Informasi dalam Pembelajaran Tingkat Sekolah Dasar pada Masa Pandemi Covid19. Jurnal Lembaga Penjaminan Mutu STKIP Agama Hindu Amlapura, 
11(2), 13-25.

Astutik, I. S. (2019). Pengembangan Media Pembelajaran Simulator Global Warming untuk Meningkatkan Hasil Belajar Siswa. Jurnal Didaktika Pendidikan Dasar, 3(1), 111-126. https://doi.org/https://doi: 10.26811/didaktika.v4i1.123

Casey, E., Kudeva, R., \& Rousson, A. (2018). Institutionalization of Religion in Schools to Intercultural Education. Jurnal Ilmiah Peuradeun, 6(1), 85-102. doi:10.26811/peuradeun.v6i1.215

Chahyanto, T. N., \& Wantoro, J. (2019). Media Pembelajaran dengan Aplikasi Berbasis Android untuk Meningkatkan Hasil Belajar Siswa dalam Mata Pelajaran Biologi di Kelas XI SMA Muhammadiyah 1 Karanganyar. Universitas Muhammadiyah Surakarta.

Fadli, F., Prestwich, A., \& Sykes-Muskett, B. (2018). Assessing Mediating Effect of Motivation Types on Competition Intervention For Physically Inactive Adults. Jurnal Ilmiah Peuradeun, 6(1), 1-16. doi:10.26811/peuradeun.v6i1.156

Farida, E. (2019). Media Pembelajaran Teknologi Digital untuk Meningkatkan Efektivitas Belajar Siswa pada Abad-21. Jurnal Didaktika Pendidikan Dasar, 3(2), 457-476. https://doi.org/https://doi: 10.26811/didaktika.v4i1.123

Hariadi, S. (2021). Pengembangan Multimedia Teks Wawanrembug Berbasis Blended Learning pada Siswa VIII. Jurnal Didaktika Pendidikan Dasar, 4(1),

https://doi.org/10.26811/didaktika.v4i1.125 39-58.

Kaylene, P., \& Rosone, T. (2016). Multicultural Perspective On The Motivation of Students in Teaching Physical Education. Jurnal Ilmiah Peuradeun, 4(1), 115-126.

Kristiningrum, K. (2020). Pengembangan Media X-Box untuk Meningkatkan Pemahaman Siswa Sekolah Dasar tentang Perkalian. Jurnal Didaktika Pendidikan Dasar, 4(1), 19-38. https://doi.org/10.26811/didaktika.v4i1.123

Kuswanto, J., \& Radiansah, F. (2018). Media Pembelajaran Berbasis Android Pada Mata Pelajaran Sistem Operasi Jaringan Kelas XI. An Nabighoh Jurnal Pendidikan Dan Pembelajaran Bahasa Arab, 14(01), 129. 
Murziqin, R., Idris, S., Usman, N. Hayati, H., Tabrani ZA. (2020). Epidemiology and psychology in handling the psycho-social problem Covid-19. Opcion, 36(91), 1310-1333. https://produccioncientificaluz.org/index.php/opcion/article/vi ew/32502

Muyaroah, S., \& Fajartia, M. (2017). Pengembangan Media Pembelajaran Berbasis Android dengan menggunakan Aplikasi Adobe Flash CS 6 pada Mata Pelajaran Biologi. Innovative Journal of Curriculum and Educational Technology, 6(2), 22-26. https://doi.org/10.15294/ijcet.v6i2.19336

Nugraheni, N. K. (2017). Multimedia pembelajaran digital untuk meningkatkan antusiasme siswa dalam belajar. Prosiding HIPKIN Jateng, $1(1)$, 31-38. http://hipkinjateng.org/prosiding/index.php/2017/article/view $/ 5 / 5$

Rosidah, F. (2021). Teknik Showing Berbantuan Multi Media Kreatif untuk Meningkatkan Keterampilan Menulis Teks Narasi. Jurnal Didaktika Pendidikan Dasar, 4(1), 169-192. https://doi.org/10.26811/didaktika.v4i1.161

Sadikin, A., \& Hamidah, A. (2020). Pembelajaran Daring di Tengah Wabah Covid-19. Biodik, 6(2), 109-119. https://doi.org/10.22437/bio.v6i2.9759

Sriningsih, H. (2019). Pengaruh Pelaksanaan Pendekatan Pembelajaran Keterampilan Proses Terhadap Antusiasme Belajar Murid inpres 12/79 Lonrae Kecamatan Taneteriatan Timur Kabupaten Bone. Universitas Negeri Makasar.

Steinbach, M., \& Afroozeh, S. (2016). Comparative Education in The Educational Systems and Problems in Likenesses and Differences Between Regions of The World. Jurnal Ilmiah Peuradeun, 4(3), 333-346.

Sugiyono. (2017). Metode Penelitian Pendidikan Pendekatan Kuantitatif, Kualitatif, dan RED. Bandung: Alfabeta.

Tabrani ZA. (2012). Future Life of Islamic Education in Indonesia. International Journal of Democracy, 18(2), 271-284.

Wahyudin, A. (2018). Pengembangan Media Pembelajaran Persamaan Kuadrat melalui Android untuk Meningkatkan Minat Belajar Siswa. Jurnal Didaktika Pendidikan Dasar, 2(1), 55-66. 
Walidin, W., Idris, S., \& Tabrani ZA. (2015). Metodologi Penelitian Kualitatif $\mathcal{E}$ Grounded Theory. Banda Aceh: FTK Ar-Raniry Press.

Yektyastuti, R., \& Ikhsan, J. (2016). Pengembangan Media Pembelajaran Berbasis Android pada Materi Kelarutan untuk Meningkatkan Performa Akademik Peserta Didik SMA. Jurnal Inovasi Pendidikan IPA, 2(1), 88-99.

https://doi.org/http://dx.doi.org/10.21831/jipi.v2i1.10289

Yusrizal, Y., \& Hanif, K. (2017). Increasing of Students' Motivation in Learning Physics Through the Use of Computer Simulation Media Viewed From Parents' Employment Background. Jurnal Ilmiah Peuradeun, 5(2), 201-212. doi:10.26811/ peuradeun.v5i2.129 